\title{
GEOCHRONOLOGY OF LATE QUATERNARY EVENTS IN NORTHEASTERN RUSSIA
}

\section{A. V. LOZHKIN}

Quaternary Geology and Geochronology Laboratory, Northeast Interdisciplinary Research Institute, Russian Academy of Sciences - Far East Branch, 16 Portovaya, Magadan 685000 Russia

\begin{abstract}
Radiocarbon-dated paleobotanical and palynological samples record complex changes of vegetation and climate in northeastern Russia during the Late Pleistocene and Holocene. Since the Kargin Interval (middle Wisconsin equivalent), which started $50 \mathrm{ka}$ ago, we can distinguish two periods that were colder than the present. The Kirgilyakh was the earliest Karginsk cool period, dating to 45-39 ka BP. The second significant cool period dates to 33-30 ka BP. The boundary between the Kargin Interval and the last Late Pleistocene glaciation (Sartan, late Wisconsin equivalent) dates from $27 \mathrm{ka}$ BP. The sharp change from herbaceous mossy tundra (Sartan) to light-coniferous larch forests (Holocene) in northeastern Russia dates to $12.5 \mathrm{ka}$ ago. The Holocene thermal maximum, linked to the expansion of woody plants into the modern barren-ground tundra, dates from 9.5-8 ka BP.
\end{abstract}

\section{INTRODUCTION}

I employed the radiocarbon method, along with paleobotanical and palynological techniques, to date climatic changes that occurred in the second half of the Late Pleistocene and Holocene in northeastern Russia. I studied alluvial deposits, buried soils and loess deposits (which form the surface of tundra (yedoma) in the Yana-Indigirka and Kolyma lowlands and in Chukotka), and alas (thermokarst basins) peat bog sections. I also examined lake-sediment core samples for paleoclimatic and paleoecological reconstructions. Figure 1 shows sampling locations.

\section{THE LATE QUATERNARY IN NORTHEASTERN RUSSIA}

The development of the geochronological scale for the late Quaternary of northeastern Russia is closely related to determining the length of the Kargin and Sartan intervals (middle and late Wisconsin, respectively; Goldthwait et al. 1965). It is likely that Kargin deposits in the Indigirka River basin, identified as the Khudzhak horizon (Goldfarb and Lozhkin 1975), correspond to the second half of the Boutellier interval in unglaciated Beringia. I also believe that the Sartan interval (the Inokchan interval in the Indigirka River basin) corresponds to the Duvanny Yar interval of Beringia (Hopkins 1982). Available paleobotanical ${ }^{14} \mathrm{C}$-dated evidence testifies to at least two relatively long periods of cooling in the Kargin interval, which began ca. $50 \mathrm{ka} \mathrm{BP}$, and is considered a relatively warm period in northeast Russia.

Early Kargin cooling was identified first from palynological and carpological data, and ${ }^{14} \mathrm{C}$ dates at the Kolyma River head, where a well-preserved young mammoth was found (Shilo et al. 1983). Soil dates of 43,500 \pm 1500 BP (MAG-495) and 44,600 \pm 2000 BP (MAG-378), from beneath alluvial deposits of Terrace III above the Kirgilyakh floodplain (the initial mammoth burial location), as well as results of 40,600 $\pm 700 \mathrm{BP}$ (MAG-366A), 41,000 $\pm 900 \mathrm{BP}$ (MAG-976) and $41,000 \pm 1100 \mathrm{BP}$ (MAG-366) obtained from soft tissue of the mammoth, established that cooling occurred at 45-39 ka BP; this interval was named the Kirgilyakh cooling.

At this time, the central regions of northeastern Russia were dominated by mountain larch foresttundra and grass-sedge mixed grass communities, which were replaced on high mountain slopes by tundra (based on carpological and palynological analysis of mammoth gastrointestinal contents and host sediments). Paleobotanical evidence also indicates that, during Kirgilyakh cooling, larch forest-tundra became widespread, probably as far as the present-day coast of the East Siberian Sea (Lozhkin 1984). It is probable that, at this time, Southworld and Gahanna glacial deposits formed 


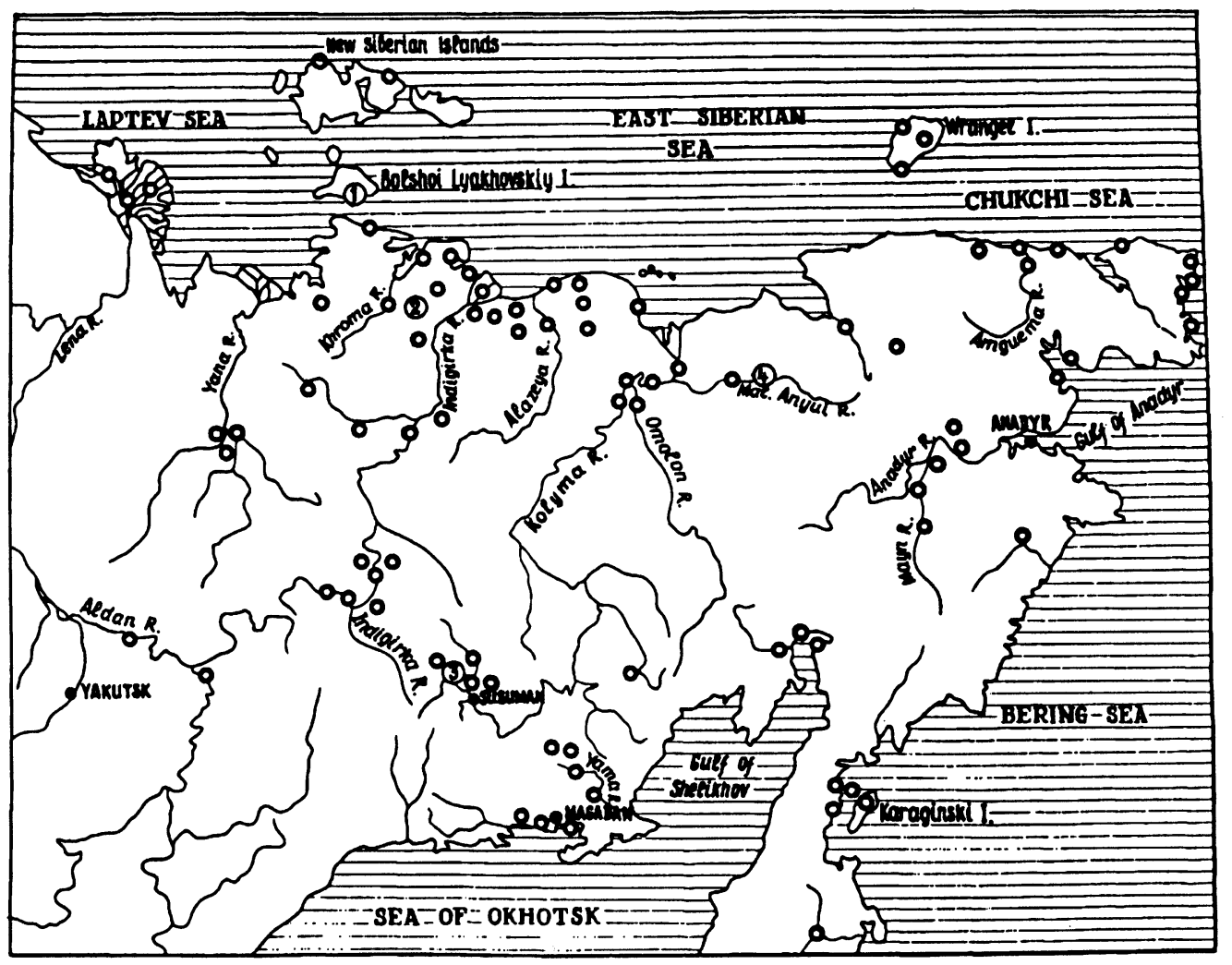

Fig. 1. ${ }^{14} \mathrm{C}$ date localities for Quaternary sequences in northeastern Russia (0); 1. Bolshoi Lyakovskiy Island mammoth; 2. Mammoth cemetery on the Berelekh River bank; 3. Kirgilyakh mammoth; 4. Anmynveem River valley mammoth

in North America; Mogador glacial drift formed in the Great Lakes area (Goldthwait et al. 1965), rather than Danwich glacial drift, as proposed by Kind (1974).

${ }^{14} \mathrm{C}$ dates of buried soils and plant remains from Kirgilyakh Terrace III alluvial deposits $(38,000$ $\pm 800 \mathrm{BP}$ (MAG-499), 36,200 $\pm 600 \mathrm{BP}$ (MAG-494) and 36,000 $\pm 650 \mathrm{BP}(\mathrm{MAG}-497)$ ) indicate significant climate warming during the Kargin interval. In the central mountainous regions of northeastern Russia, forest-tundra was replaced by light coniferous larch forest, possibly including Siberian spruce and Manchurian alder. East of the Verkhoyansk ridge, such remains have been preserved only at the Yama River, $180 \mathrm{~km}$ east of Magadan. Permafrost disappeared in the Yana-Indigirka and Kolyma lowlands during climatic warming, resulting in the formation of large thermokarst basins (alas) and pseudomorphs along recurrent cavern-lode ice. The remains of brushwoods and trees found in the pseudomorphs and in the buried alas deposits indicate an expansion of forest vegetation, including the Kajander larch, into the zone of modern tundra.

The second cooling period during the Kargin interval was revealed by palynological and cryogenicfacies analyses of glacial deposits (yedoma suite). Changes in the cryogenic-facies environment, reflected in glacial sections of the Khroma, Keremesit and other rivers (Yana-Indigirka lowland), and new growth of cavern-lode ice was followed by rapid changes in pollen spectra (Ovander $e t$ al. 1987). These spectra, characterized by high grass, wormwood and mixed grass and by almost total absence of brushwood, reflect the dominance of barren tundra-type grass-moss, which re- 
placed forest and brushwood tundra (which developed in lowlands during earlier warming). Pollen changes and reactivated growth of recurrent cavern-lode ice were ${ }^{14} \mathrm{C}$-dated from glacial-complex sediments in the Khroma and Keremesit River valleys at 31,000 \pm 1000 BP (MAG-425) and 30,000 $\pm 600 \mathrm{BP}$ (MAG-660). Thus, one can assume that the second Kargin cooling corresponds to the Konoshchelsk cooling (33-30 ka BP) identified in the Near-Enisey region of Siberia (Kind 1974). This interval also corresponds to ${ }^{14} \mathrm{C}$ results from soft tissue $(32,000 \pm 900 \mathrm{BP}$ (MAG-316) and $32,030 \pm 1170 \mathrm{BP}$ (MAG-316A)) from a mammoth found in yedoma-suite deposits on the south shore of Bolshoi Lyakhovski Island (Lozhkin 1984); it is also supported by dates of 32,810 \pm 720 $\mathrm{BP}$ (MAG-1001A) and 32,890 $\pm 1200 \mathrm{BP}$ (MAG-1001) obtained from fragments of skin, connective tissue and muscle of an adult mammoth found in the Enmynveem River valley (Maly Anyui River basin, central Chukotka). Lake-bog deposits that contained the remains had a relatively low pollen content; pollen production at the time the Enmynveem mammoth population existed is estimated as 4-10 times below that of the contemporary light larch forests of the Malyi Anyui River basin. It is likely that vegetation of the central Chukotka area during the second Kargin cooling was characterized by dry grass tundras.

Climate warming, reflected in pollen spectra from the Kirgilyakh alluvial Terrace II deposits, and the overlying buried soil, was ${ }^{14} \mathrm{C}$-dated at $29,800 \pm 700 \mathrm{BP}$ (MAG-506) and 28,700 $\pm 200 \mathrm{BP}$ (MAG-503) and corresponds to Lipovsk-Novoselovsk warming in Siberia. Larch forests were widespread in the Kolyma mountain regions, and included Siberian spruce and Manchurian alder. Large brushwood, larch and birch tree-trunk remains found in late Quaternary deposits of the Kolyma lowland dated to $27,860 \pm 450 \mathrm{BP}$ (MAG-109), confirm the transport of forest remains to the zone of present tundra during the last warming in the Kargin interval.

The last Late Pleistocene glaciation (Sartan, Inokchan) is well-documented by ${ }^{14} \mathrm{C}$ dates. Many results are from mammoth remains from the Yana-Kolyma lowland. Among them is a large Berelekh burial in the Indigirka River basin, dated from mąmmoth soft tissue at $13,700 \pm 80 \mathrm{BP}$ (MAG-114). Sediments that include the 2-m-thick bone-bearing horizon constitute the middle part of the Berelekh River 14-m Terrace II deposits; pollen spectra reveal a high content (up to 90\%) of herbs, dominated by grass, wormwood (Artemisia) and Caryophyllaceae (pink family) pollen. The spectra illustrate vegetation of the extremely cold and dry Late Pleistocene climate and enable correlation of the herb pollen zone to modern arctic communities.

Identification of the herb pollen zone and its ${ }^{14} \mathrm{C}$ dating are important in reconstructing Late Pleistocene paleoclimates and vegetation. A similar pollen zone is found in other phytogeographic areas, e.g., the Kolyma River, where its Sartan age has been determined by ${ }^{14} \mathrm{C}$ dates of $17,000 \pm$ $200 \mathrm{BP}$ (MAG-638), 15,000 $\pm 200 \mathrm{BP}$ (MAG-468), 15,000 $\pm 500 \mathrm{BP}$ (MAG-636) and 14,980 \pm 100 BP (MAG-470). Pollen analysis of alyoshkin suite deposits, identified by Sher (1971) in a section of the 15-m Kolyma terrace, indicates development of mixed-grass associations, distinct from modern vegetation represented by light larch forests.

Pollen analysis revealed the dominance of herb pollen (to 92\%) in the Kolyma central mountain regions, in a section of the Berelekh River 20-m terrace deposits; grass, sedge, wormwood and pink family types prevail. Brushwood is represented only by single grains of slender birch, alder grove, willow and Japanese stone pine. The spectra are similar to subfossil pollen spectra of barren tundra in northeastern Russia, but a complete analog among surface spectra has not yet been identified. The abundance of Siberian club moss in the spectra of herb pollen is due to the development of cryoxeric herb-club moss communities on mountain slopes, especially those with southern exposures, during the Sartan interval. 
In a section of the 20-m terrace of the Berelekh River, the deposits characterized by tundra communities consisting of herb pollen are overlain by peat $(0.7 \mathrm{~m})$, which contains larch forest and mountain forest-tundra pollen. Climatic warming, as reflected by peat pollen spectra, was ${ }^{14} \mathrm{C}$-dated at $12,450 \pm 500 \mathrm{BP}$ (MAG-616) (the lower peat layer) and 11,750 $\pm 400 \mathrm{BP}$ (MAG-617) (the upper peat layer). These results are similar to a date of $11,870 \pm 60 \mathrm{BP}$ (MAG-117) on the buried soil overlying the bone-bearing horizon at the Berelekh mammoth burial, which has pollen spectra similar to those of modern communities of light larch forest in the Berelekh River basin. The replacement of tundra by forest is clear in spectra of a lake sediment core, drilled in the central part of the third Lake Elikchan, situated on the Okhotsk Kolyma interfluve at the Yama River head.

Thus, ${ }^{14} \mathrm{C}$ dates obtained from different phytogeographic regions of northeastern Russia suggest that a sharp vegetation change, from herb-moss tundra to larch-forest tundra and light coniferous-larch forest, occurred $c a .12,500-12,000 \mathrm{BP}$. These changes in vegetation composition were undoubtedly caused by a substantial warming that played a decisive role in the extinction of mammoth fauna.

To understand the development of Late Pleistocene vegetation on the east margin of northeastern Russia, I consider the latest set of ${ }^{14} \mathrm{C}$ data from the $30-\mathrm{m}$ sequence of heavily iced sediments of the Ledovy Obryv exposure in the Anadyr River basin. These dates cover the interval from 42,000 $\pm 1300 \mathrm{BP}$ (MAG-804) to $19,500 \pm 500 \mathrm{BP}$ (MAG-815); they are accompanied by pollen spectra that contain up to $80 \%$ herbaceous plant pollen, grass, sedge, wormwood, and pink family pollen. Paleobotanical analysis reveals a distinct boundary where large plant remains (brushwood roots and branches) typical of the deposits of the lower section are replaced by small roots of exclusively herbaceous plants (similar to plant remains in heavily-iced yedoma-suite deposits of the Yana-Indigirka and Kolyma lowland). This probably reflects the replacement of vegetation of large brushwood tundra that existed during the Kargin interval (42,000 \pm 1300 BP (MAG-804), 38,000 \pm 1000 BP (MAG-802), 35,000 \pm 1000 BP (MAG-803), 34,500 $\pm 500 \mathrm{BP}$ (MAG-801) and 31,400 $\pm 500 \mathrm{BP}(\mathrm{MAG}-805)$ ) by the moss-herb and herbaceous tundras that developed in the cool and dry climate of the last Late Pleistocene glaciation, dated as 23,500 $\pm 500 \mathrm{BP}$ (MAG-813), 22,300 \pm 200 $\mathrm{BP}$ (MAG-814) and 19,500 $\pm 500 \mathrm{BP}$ (MAG-815).

The replacement of plant cover in the Ledovy Obryv exposure is dated at 27,400 $\pm 500 \mathrm{BP}$ (MAG-810) and 27,000 \pm 500 BP (MAG-811). These results correspond to the boundary of the Kargin and Sartan intervals. Pollen spectra of the herbaceous pollen zone are consistent with spectra obtained by analysis of the Puetten section in Chukotka in the Amguema River basin (Ivanov et al. 1984). These strata are dated at 30,600 $\pm 900 \mathrm{BP}$ (MAG-678) and 28,900 $\pm 800 \mathrm{BP}$ (MAG-674). Puetten spectra are dominated by herbaceous plant pollen, especially wormwood and grass, and are similar to the spectra of deposits formed in the Kolyma and Indigirka River basins (17-13 ka BP). Therefore, the ${ }^{14} \mathrm{C}$-dated paleobotanical samples indicate the existence of peculiar herbaceous communities in northeastern Russia during the last glaciation (the Sartan interval), and in the eastern areas of the region during the Kargin interval of the Late Pleistocene. Their occurrence in Chukotka seems to have been caused by the extensive land exposure in place of the present-day shelf to the north and south of the contemporary Bering Strait. Species migrated via this land bridge to Alaska and the Yukon, where a similar herbaceous pollen zone, dated at 33-15 ka BP is identified from analysis of lake deposits (Cwynar 1982; Ritchie 1982, 1984).

Complex climate changes in northeastern Russia at the Pleistocene-Holocene boundary and in the Early Holocene should be related to glacial melting and rising sea level. A series of ${ }^{14} \mathrm{C}$ dates from brushwood (including alder grove) and tall birches found in the alas deposits within the contemporary herb-moss and herb-brushwood tundra (with decumbent willow brushwood and, to the south, slender birch) confirms the warming in northeastern Russia ca. 9500-8000 BP. During 
this phase, elements of forest vegetation advanced as far north as the Novosibirsk Islands, which were then still part of the continent. Expansion of forest vegetation into the zone of modern barren-ground tundra indicates that the Holocene thermal maximum occurred during the Boreal period. During the Atlantic period (8000-5000 BP), as palynological, carpological and ${ }^{14} \mathrm{C}$ data have shown, vegetation of northeastern Russia acquired modern characteristics. At the same time, the study of pollen at archaeological sites in the upper Kolyma basin and sections of lowland alas deposits reveal at least two cooling intervals during the Holocene. One occurred at the beginning of the Atlantic period (7900-7500 BP), the other at $4500 \mathrm{BP}$. These data indicate the following stages of vegetation development in the Holocene of northeastern Russia: Preboreal: 10,500 (10,200)-9500 BP; Boreal: 9500-8000 BP; Atlantic: 8000-5000 (4500) BP; Subboreal: 5000 (4500)-2500 BP; and Subatlantic: $2500 \mathrm{BP}$ to present.

\section{REFERENCES}

Cwynar, L. 1982 A Late-Quaternary vegetation history frorn Hanging Lake, Northern Yukon. Ecological Monographs 52(1): 24 p.

Goldfarb, Yu. I. and Lozhkin, A. V. 1975 Vegetation history of the Northeastern USSR during the late Pleistocene and Holocene. Bulletin of Commission on the Quaternary Period 43. Moscow, Nauka: 78-89.

Goldthwait, R. P., Dreimanis, A., Forsyth, J. L., Karrow, P. F. and White, G. W. 1965 Pleistocene deposits of the Erie Lobe. In Wright, H., Jr. and Frey, D. C., eds., The Quaternary of the United States. Princeton University Press. Russian translation: Chetvertichnyi Period SSA (1). Moscow, Mir Publishers: 98-115.

Hopkins, D. M., Matthews, J. V. Jr., Schweger, C. E. and Young, S. B., eds. 1982 Aspects of the Paleogeography of Beringia during the Late Pleistocene. Paleoecology of Beringia. New York, Academic Press: 3-28.

Ivanov, V., Lozhkin, A. V., Kalnichenko, S. S. et al. 1984 Late Pleistocene and Holocene of the Chukotka Peninsula and North of Kamchatka. In Geology and Mineral Resources of Northeast Asia. Vladivostok, Far East Scientific Center of the USSR Academy of Sciences: 33-44.

Kind, N. V. 1974 Geochronology of the Late Anthro- pogene from Isotope Data. Moscow, Nauka: $255 \mathrm{p}$. Lozhkin, A. V. 1984 Climate and vegetation changes in West Beringia during the late Pleistocene. In Geology and Mineral Resources of Northeast Asia. Vladivostok, Far East Scientific Center of the USSR Academy of Sciences: 29-32.

Ovander, I. G., Lozhkin, A. V., Bashlavin, D. K. and Zhigulevtseva, S. N. 1987 The paleogeographic environment during the formation of yedoma suite in the Yana-Indigirka lowland. In Quaternary Period of Northeast Asia. Study of the Northeastern Multidisciplinary Research Institute of the Far East Branch of the USSR Academy of Sciences, Magadan: 119-134.

Ritchie, J. C. 1982 The Modern and Late-Quaternary vegetation of the Doll Creek Area, North Yukon, Canada. New Phytologist 90: 563-603.

1984 Past and Present Vegetation of the Far Northwest of Canada. Toronto, Canada, University of Toronto Press: $251 \mathrm{p}$.

Sher, A. V. 1971 Mammals and Stratigraphy of the Pleistocene in the Far Northeast of the USSR and North America. Moscow, Nauka: 310 p.

Shilo, N. A., Lozhkin, A. V., Titov, E. E. and Shumilov Yu. V. 1983 The Kirgilyakh Mammoth (Paleogeographic Aspect). Moscow, Nauka: 214 p. 